\title{
DOCUMENTATION OF OGBANIGBE FESTIVAL OF OWERRE-OLUBOR PEOPLE (IKA NORTHEAST LOCAL GOVERNMENT AREA), AGBOR, DELTA STATE
}

\author{
Okafor Justina Enoh (PhD) ${ }^{1 \square}$ \\ ${ }^{1}$ Department of Music, University of Delta (Unidel), Agbor, Delta State, Nigeria
}
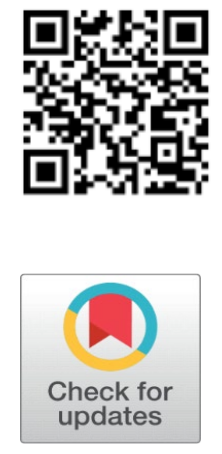

Received 01 April 2021

Accepted 06 May 2021

Published 10 May 2021

Corresponding Author

Okafor Justina Enoh,

okafor.enoh@yahoo.com

\section{DOI}

10.29121/shodhkosh.v2.i1.2021.25

Funding: This research received no specific grant from any funding agency in the public, commercial, or not-for-profit sectors.

Copyright: (C) 2021 The Author(s). This is an open access article distributed under the terms of the Creative Commons Attribution License, which permits unrestricted use, distribution, and reproduction in any medium, provided the original author and source are credited.

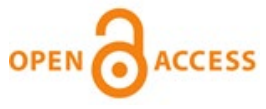

\section{ABSTRACT}

Identity is that characteristics that distinguishes, differentiates, and separates one community from another in terms of ideology, belief systems, organizational structures, mode of dressing, dialect, communal activities such as festival commemoration. Enshrined in one of man's communal activities is the yearly celebration of New Yam festival. New Yam Festival has been coined with various names in many climes in Nigeria. In Owerre-Olubor community, New Yam festival is associated with Ogbanigbe (Ime-Egwu) festival similar to that of Obie community of Aniocha nomenclature. The paper employed descriptive analysis, oral interview as well as related materials. The paper focused on Ogbanigbe (Ime-Egwu) festival, the origin of Owerre-Olubor community of Ica Northeast Agbor, Delta State, Nigeria including musical instruments and some songs used during the festival celebration. Four sampled song texts were selected and captured while one musical example from the four song texts selected was analyzed. The paper conclude that documentation is the only way to preserve culture of a people including music peculiar to such culture for the next generation in order to escape extinction.

Keywords: Festival, Ogbanigbe

\section{INTRODUCTION}

Man is an entity, man has an identity, and man has culture and belief systems that guide his day-to-day activities. It is these characteristics of man that has given birth to the various cultures of the world today. In an attempt to differ and separate from one another man has invented his own ideology, dress styles, manner of greetings, marriage ceremonies, naming ceremonies, death ceremonies, dance styles, songs, festivals to mention a few, of course, these are also affected by their geographical locations. One of the activities engaged in by man is the festival ceremony. This is done on yearly basis by different sociocultural entity at an agreed date and month of the year by different communities within a geographical nomenclature. The English derivative of the term 'festival' has come to be applied to gatherings in which several arts are celebrated Michael (1996). According to Ehiwario (2005), festivals are very significant form of communal activity; they call for the best that any 
particular 'also explained that to most Nigerians a festival is that chain of activities, celebrations, ceremonies, food, drink, and rituals, which mark the continuity of culture in an environment. These festivals occur at appointed times in the lunar calendaand mark the rhythm of life. Virtually every one of them has its characteristic or associated music or dance... In a huge basket, we can find a vast array of traditional festivals and ceremonies that traditionally mark either the rhythm of life, the life rites, and appointed rituals and ceremonies that dot the traditional lunar calendar of each ethnic group in Nigeria (p. 4, 5).

Nigeria is replete with diverse ethnic/cultural groups as highlighted above these ethnic groups have their own specific and sometimes interrelated/similar festivals with variations in performance mode which are performed according to their lunar calendar. Delta State is ethnically diverse with people and numerous languages spoken in the State. Each community has at least one festival and most are celebrated annually while some are biennial. Among communities whose festivals are celebrated annually is an ethnic group in Delta State. This entity namely Owerre-Olubor community is domicile in Ica Northeast Local Government Area Agbor, Delta State. Owerre-Olubor town is situated between Akumazi Umuocha, UteOgbeje, Ekuoma and Obior. Owerre-Olubor entity celebrates two festivals every year mainly Igwe festival and Ogbanigbe (Ime-Egwu) festival. The celebration of Ogbanigbe (Ime-Egwu) is the pivotal highlight of this paper because it's of importance and chief festival celebrated by Owerre-Olubor community. Although Ogbanige (Ime-Egwu) festival is claimed to have been originated from Obior community, who are close community to Owerre-Olubor community there is no clear narratives on the origin of the said festival.

\section{GEOGRAPHICAL LOCATION /BRIEF HISTORICAL BACKGROUND OF OWERRE-OLUBOR COMMUNITY}

Owerre-Olubor community of Ica Northeast Local Government Area of Delta State is surrounded by several neighbouring villages. These include Umunede, Akumazi Umuocha, sharing bounding with Owerre-Olubor to the west, Obior to the east-west, Ute-Ogbeje to the south, and Ekuoma to the north. The father of Owerre is Olubor. Owerre gave birth to five children, three legitimate children namely, Onofo, Agboma and Etiti and two others namely Ese and Ikpulu. These five children made up Owerre-Olubor community. Thus, Owerre-Olubor community is a conglomeration of five villages namely.

1) Umuonofo

2) Umuagboma

3) Etiti

4) Umuikpuru and

5) Umuese or Umude-ese

During the celebration of Ogbanigbe festival, these five villages assemble together to worship in the shrine of 'Edofi' - this shrine ('Edofi') was brought from Ndokwa in Kwale according to oral history. Different drums are used for the dance while each village meet at the Chief's palace before going to visit the chief holding the title of Olubor (the first son). This title is rotational, so also is the chieftaincy and kingship titles. According to oral tradition, the commencement of Ogbanigbe (ImeEgwu) as a festival in Owerre-Olubor community was originally initiated by their 
ancestors in commemoration of the unique funeral dance that accompanied the corpse of Diagbor, the father of Owerre on his demise at Ejeme where he was receiving treatment, down to Owerre-Olubor where he was buried. After some thousands of years of this celebration due to change and continuity, the dance/rites used to accompany the deceased corpse of Diagbor metamorphosed into what is known and called Ogbanigbe (Ime-Egwu) festival. It began to be commemorated in recent years at the maturity of new yams and this change took effect after the inception of the Ogwudes.

\section{OGBANIGBE FESTIVAL (IME-EGWU)}

Oral tradition had it that 'Ogbanigbe' otherwise called 'Ime-Egwu' for hundreds of years is a jubilant dance and celebration in commemoration of the survival through the second part of the ordeal of farming season. As noted by Mbiti (1975) in his write-up "The Prayer of African", that harvesting is usually associated with some festivals, prayers are said, some incantations are recited by the people in the traditional capacity as priests, diviners, elders, heads of families and so on. This above assertion would be said of the Owerre-Olubor people that engage in various activities that lead to the celebration of Ogbanigbe 'Ime Egwu'.

\section{ACTIVITIES ASSOCIATED WITH THE OGBANIGBE FESTIVAL}

The second part of the farming season includes clearing of farmlands, cultivation of yams and other farm crops, staking of yams and weeding of already planted crops begins from after the Igwe festival. One can safely say that Ogbanigbe (Ime-Egwu) festival is a continuation from Igwe festival, although emphasis is not placed on the Igwe festival. Oral history has it that when in August every year, the Ogwude of Owerre-Olubor observes that the yams are getting matured or are really matured for harvesting, he surmons the elders, his council of chiefs and their deity (edofi) priest to a meeting. The Ogwude then fixes a date for the new yam festival and celebration, after the deity priest must have performed some rites to the edofi their deity god. The New Yam festival and Ogbanigbe festival are interwoven for the new yam festival marks the beginning of Ogbanigbe 'Ime-Egwu' festival. The new market days are Nwkor or Ogba. According to Onwuekwc (2005) 'elaborate preparations are made, and often people who live outside the town in question endeavour to come for the occasion. Ehiwario (2005) added that 'festivals create room for people to renew their friendship, since members of the feasting community travel from far and near to felicitate with their friends, well-wishers, families, relations, and other members of the community at home. Festivals are very significant forms of communal activity; they call for the best that any particular society can produce. While Nketia (1974) corroborated that the degree of social cohesion in such communities is usually very strong, not only may the members know one another but also that, they may be bound by a network of social relations Nketia (1974). This is also applicable to the people of Owerre-Olubor community of Ika Northeast Local Government of Delta State. All sons and daughters of OwerreOlubor community home and abroad are invited for this august occasion. Also, publicity is created through various medium to reach all and sundry. Ogbanigbe festival is usually celebrated either in September or October of every year as the season may warrant. 


\section{OPERATUS MODERADUM OF OGBANIGBE FESTIVAL CELEBRATION}

A festival is a day set by the community to celebrate certain events that happened in the past. It is a day of merry making, and so, every member of the community looks forward to the day of the festival. Mbiti (1975) noted that some festivals involve paying homage to the dead. In the rituals associated with this festival, the spirit of the dead is invited to participate in the merry making and prayers to them to protect and provide for the people are made. Turner (1971) on the other hand, observed that in most African society prayers predominate most festivals in addition to thanksgiving to the celebrations. Special oblations and sacrifices are also part of the ceremonies. From the evening of the New Yam celebration, the elders and chiefs enter the period of solemnity known as $I b a-n z u$ (that is, holy week). From Iba-nzu to actual day of the festival, there would be night of wake-keeping accompanied with dances done by the provosts to the titled men and many others. The festival lasts for six days. The sixth day is a festive day till the end of the festival which is Igbu-Agbo. The less in rank among the titled men lead the early celebration of dances till they go and hand over the leadership to the 'Iyase' of the town. The Iyase then leads the crowd to important personalities, especially elders and heads of villages and to other places and spots that are of interest. The day is one of the happiest days for the entire citizens of Owerre-Olubor community.

Neighbouring communities far and near take delight in coming to observe the celebration, these usually stand along the streets and roadside; many of them even join the participating community in the dancing because of its thrilling nature. The last place visited by the lyase, titled men and crowd is the palace of the logwude of Owerre-Olubor. After much dancing and entertainment, all leave the Ogwude's palace to perform the rite for Igbu-Agbo. This Igbu-Agbo is done in the evil-bush or forest known as Ejo-Ofia Ikpekpe (that is, cemetery)'

No stranger is allowed to follow them except the titled men and few selected dancers with their drums go to this evil-bush to perform the rite of Igbu-Agbo - these return back to their homes in silence (this time there is no drumming). The performance of Igbu-Agbo signifies the end of dance performance associated with the Ogbanigbe festival. It is worthy of note here that elderly men who did not accompany those who went to the evil-bush (Ejo-Ofia), perform their own Igbu-Agbo in front of their compounds saying exactly the same words altered previously by the titled men and selected dancers who went to the evil-bush thus: "Odoh-Ololokomi" seven times. Prior to the performance of Igbu-Agbo rites, the elders go to 'Ilo-Chi to give thanks to "Chi" (God) for sustenance especially for allowing them to eat of the fruits of their labour. This is usually done on the firth day (izu). It is believed by the Owerre-Olubor people that after the celebration of Ogbanigbe festival, peace exists all through the community of Owerre-Olubor land.

\section{INSTRUMENTS/SELECTED SONGS USED IN OGBANIGBE FESTIVAL}

In African society, various instruments are associated with various ceremonial performances according to specific function performed by these instruments. In Ogbanigbe festival celebration certain instruments were used and these include.

1) Aturuaka (elephant tusks) an aerophone instrument. 
2) Nne-Egede (mother drum - three or four in number) a membranophone instrument.

3) Umu-Egede (children drum - not of the size with the 2 above) also a membrophone.

4) Eboma (Gong - two or more as the case may be) an idiophone instrument and

5) Ishaka (Maracas) also idiophone.

These instruments are used to entertain the populace during Ogbanigbe (Ime$E g w u$ ) festival celebration. Some popular songs used include Owerre gbali gbali, Aho unwu mulu aho, Oo Nelone ilolo and Oo Onyeoma ejene Ogwu. The above selected songs are tabulated below including its English equivalent.

\section{Song I}

\section{Owerre gbali gbali}

Owerre, gbali, gbali - o-ho!

Owerre, gbali, gbali - oho!

gbali, gbali - oho!

gbali, gbali - oho!

(Emphasis lye-wo, Iye-wo, Iye-wo;)

Iye-wo, Iye-wo, Iye-wo

gbali, gbali -o-ho!

Ony'iwe erie nga na ji

Ony'iwe erie ngana akasi

Ony'iwe erie ekpu nodene, rie]

otori,Nke hoduni - o-ho!]

gbali, gbali - oho!

gbali, gbali - oho!

gbali, gbali - oho!

gbali, gbali - oho!

Iye-wo, Iye-wo, Iye-wo;

Iye-wo, Iye-wo, Iye-wo;

Iye-wo!

gbali, gbali - oho!

gbali, gbali - oho!

\section{Owerre come together}

Owerre, unite, come together -oho!

Owerre,unite,cometogether -o-ho!

come together -o-ho!

come together -o-ho!

(anexclamation, as a way ofputting emphasis on the song)

come together -o-ho!

Enemy has eaten yam

Enemy has eaten akasi

Enemy has eaten what will kill him - o-ho!

come together -o-ho!

come together -o-ho!

come together -o-ho!

come together -o-ho!

(an exclamation, as a way of putting emphasis on the song)

come together -o-ho!

come together -o-ho!

The above song is sung intermittently with the following songs below. 


\section{Song II.}

Aho Unwu Malu Aho Nwa

Aho unwu nalu Aho nwa - o-o-o-ho

Dine nwiaye anu-ogwu ori-o-o-o-ho

\section{Song III.}

O-O-Nelo-ne ilolo

O - o - Nelo-ne ilolo

Nwabuzo Ukpali nelone - ilolo

Onye nweli ilolo, ya lone, ilolo

Nwabuzo Ukpali ya lone ilolo

Onye nweli ilolo, ya lone, ilolo

Aho we no gbu ohere noli alinma ilolo

\section{Song IV.}

O-O-Onye-Oma Ejene Ogwu

o-o-onye-oma ejene ogwu

onye-oma ejene ogwu

onye-oma ejene ogwu

Ihe ri-nma Ogwu-eri (2ce)

O-o-onye-oma ejene ogwu

onye-oma ejene ogwu

onye-oma ejene ogwu

Onwenna nw'Ogboko,ozu nwuhu

Ochoma ebo

O-o-onye-oma ejene ogwu

Onwenna nw'Ogboko,ozu nwuhu

Ochoma ebo

\section{the Year of Famine}

the year that famine existed-o-o-o-ho

Husband and wife fought for ori -o-o-o-ho
0-O-Think, Think

0 - o - think, think

Nwabuzo Ukpali, continue to think Whosoever can think, keep thinking

Let Nwabuzo Ukpali think

Whosoever can think, keep thinking

The year that juju priest is killed, is never

$$
\text { good - think }
$$

it is the good thing that war takes (2ce)

O-o- do not go to war

do not go to war

do not go to war

Onwenna daughter of Ogboko corpse looks

for the family

0-o- do not go to war

Onwenna daughter of Ogboko corpse looks

for the family

\section{SHORT ANALYSIS OF MUSICAL EXCERPTS OF SONG TEXTS FOUR “DO NOT GO TO WAR}

Oral translation of song texts Four (4) into noted music is in Key C. The music is characterized by short notes and long notes, sequence, and repetition. It has a very short-range starting from $\mathrm{G}$ below middle $\mathrm{C}$ to $\mathrm{F}$ above the middle $\mathrm{C}$ that is from (G A B C D E F) as shown on the staff below. 


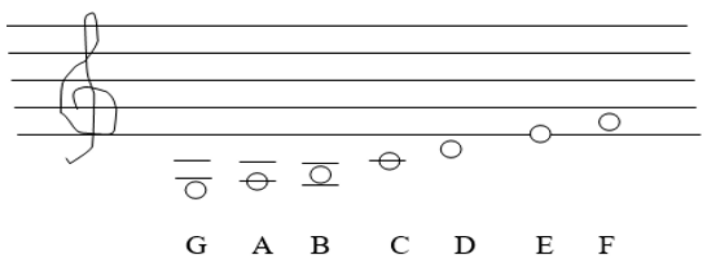

Re-arranged in the Scale of $C$ thus:

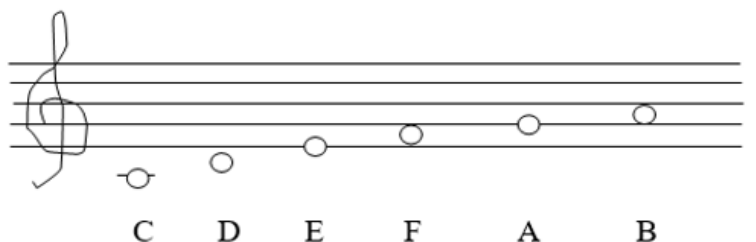

The music is in a six - scale formation as opposed to major and minor scale formation which is arranged from the first note (root) to the eighth note (octave) for instance alphabet ( $A$ to $A, B$ to $B, C$ to $C$ and so on). The melodic structure is characterized with various motions such as conjunct, disjunct, clockwise, and anticlockwise movement. It has an intervallic structure of a $6^{\text {th }}, 2^{\text {nd }}, 4^{\text {th }}$ and a $3 \mathrm{rd}$. The music also has a rhythmic structure that is characteristic of African music. See musical excerpt below:

\section{Melodic Structure}

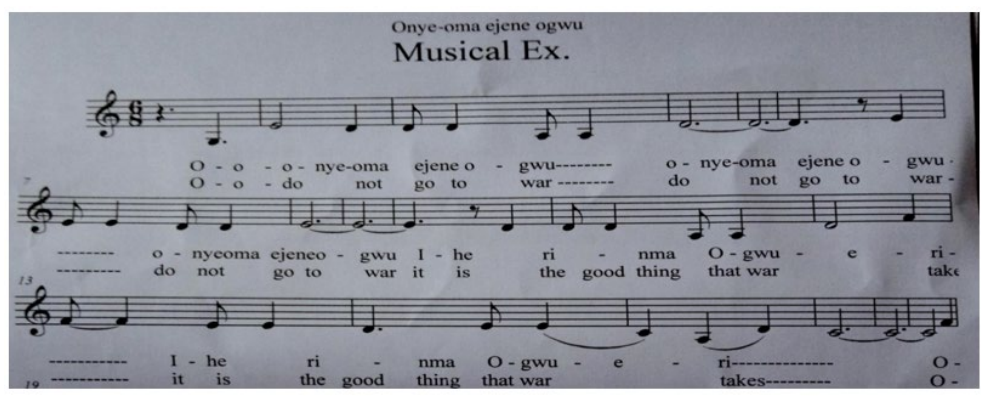

Rhythmic Structure

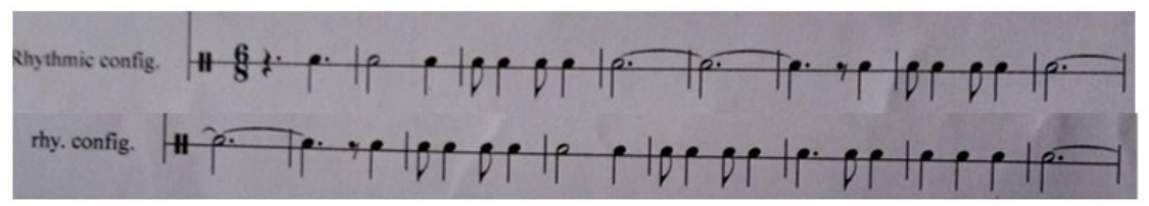

\section{ANALYSIS OF SELECTED SONG TEXTS IN ENGLISH EQUIVALENT}

\section{Song Text 1: Owerre Come Together}

Owerre, unite, come together -o-ho! 
Owerre, unite, come together -o-ho!

Come together -o-ho!

Come together -o-ho!

Come together $-\mathrm{o}-\mathrm{ho}$ !

Enemy has eaten yam

Enemy has eaten akasi

Enemy has eaten what will kill him - o-ho!

Come together -o-ho!

Come together -o-ho!

Come together -o-ho!

Come together -o-ho!

Come together -o-ho!

Come together -o-ho!

\section{Song Text 2: The Year of Famine}

The year that famine existed-o-o-o-ho

Husband and wife fought for ori -o-o-o-ho

\section{Song Text 3: 0-0-Think, Think}

0 - o - think, think

Nwabuzo Ukpali, continue to think

Whosoever can think, keep thinking

Let Nwabuzo Ukpali think

Whosoever can think, keep thinking

The year that juju priest is killed, is never good - think

\section{Song Text 4: Do Not Go to War}

0-o- do not go to war

Do not go to war

Do not go to war

It is the good thing that war takes (2ce)

0-o- do not go to war

Do not go to war

Do not go to war

Onwenna daughter of Ogboko corpse looks for the family

0-o- do not go to war

Onwenna daughter of Ogboko corpse looks for the family 
Traditionally, a text is understood to be a piece of written or spoken material in its primary form (as opposed to a paraphrase or summary). A text is any speech of language that can be understood in context. It may be as simple as 1-2 words (such as a stop sign) or as complex as a novel. Any sequence of sentences that belong together can be considered as text Thoughtco (2021) Texts whether written (composed) or unwritten (sung orally) are an important aspect of music. Although there are music compositions without texts being associated to them, a good percentage of music composed, or song orally are generally associated with texts. Most of the lines of the four song texts under consideration were repeated probably for emphasis; hence repetition technique which is one of the common features of African music and music of other world culture featured prominently in song texts 1, 3 and 4. Also the song texts are replete with figurative statements thus:

- Enemy has eaten yam

- Enemy has eaten akasi

- Husband and wife fought for ori

- Let Nwabuzo Ukpali think

- The year that 'juju priest' is killed, is never good

- corpse looks for the family

Each song texts have very important messages sent to the audience which in this case is the Owerre-olubor community and Agbor municipality in general. The song text(s) spoke of unity among Owerre-olubor community. The song text(s) also made fun of famine indicating and or alluding that during famine there is the tendency to horde food which may lead to various vices an instance is the fight between husband and wife as indicated in song text example 2. The song text in example 3, shed light on the traditional belief of Owerre-olubor people revealing their belief on the role of the priest; that the year the priest is killed is very disturbing probably signifying a bad omen while song text 4 , is an appeal to the people of Owerre-olubor community not to engage in war because war do not bring good rather wastage and disunity. The song texts are also characterized with long and short prose. Many world cultures celebrate one form of festival or the other often times associated with music. These songs often talk about the story and history of the people, the travail and or victory of such culture. The four song texts under consideration portray various pictures; it emphasized the importance and imperativeness of 'unity', the effect of 'famine', 'omen' and the devastating effect of war and encourages peaceful cohabitation among member communities. The bane of some societies today is the devastating effect of war with its attendant sibling 'famine'. It is a fact that development and progress of any society lie firmly on peaceful co-existence in any country and among member nations.

\section{CONCLUSION}

A brief historical account of the emergence and metamorphosis of OwerreOlubor community of Ika northeast local government area of Delta State, Nigeria was highlighted. Also highlighted is the community's festival 'Ogbanigbe festival' modus operandus including instruments and some songs used during the festival celebration. It is noteworthy that some of the song texts used during 'Ogbanigbe 
festival' celebration teaches about moral values, the dignity of labour, self-reliance, and the importance of dwelling together in unity instead of warring with one another - recognizing the need for communities to dwell together in order to advance communal development which is also a reflection of the State and the Nation Nigeria in general.

\section{REFERENCES}

Delta State Goverment (2018, March 2). https://www.deltastate.gov.ng/

Ehiwario, M.O. (2005). "Music in Nigerian Festivals." JANIM : A Journal of the Association of Nigerian Musicologists, (1)2, 64-65.

Mbiti, J. S. (1975). Prayers of African Religion. SPCK Publishing. https://amzn.to/3DS1NQb

Michael, K. (1996). The Concise Oxford Dictionary of Music (Oxford Quick Reference) (4th ed.). Oxford University Press. https://www.abebooks.co.uk/ConciseOxford-Dictionary-Music-Quick-Reference/30790928737/bd

Nketia, J. H. K. (1974). The music of Africa. New York : W.W. Norton \& Company. http://www.worldcat.org/oclc/841677

Okafor, R.C. (2005). Music in Nigerian festivals. Journal of the Association of Nigerian Musicology (JANIM), (1)2, 4.

Onwuekwc, A. I. (2005). An Analyses of Ekelebcm Instrumental Music And Its Role In Festival In Uga. Journal of the association of Nigerian musicologists. (1)2, 99.

Thoughtco (2021, April 22). https://www.thoughtco.com/

Turner, W. J. (1971). Music and life. London : Methuen \& co., ltd.. https://catalog.hathitrust.org/Record/001466321

\section{APPENDIX I}

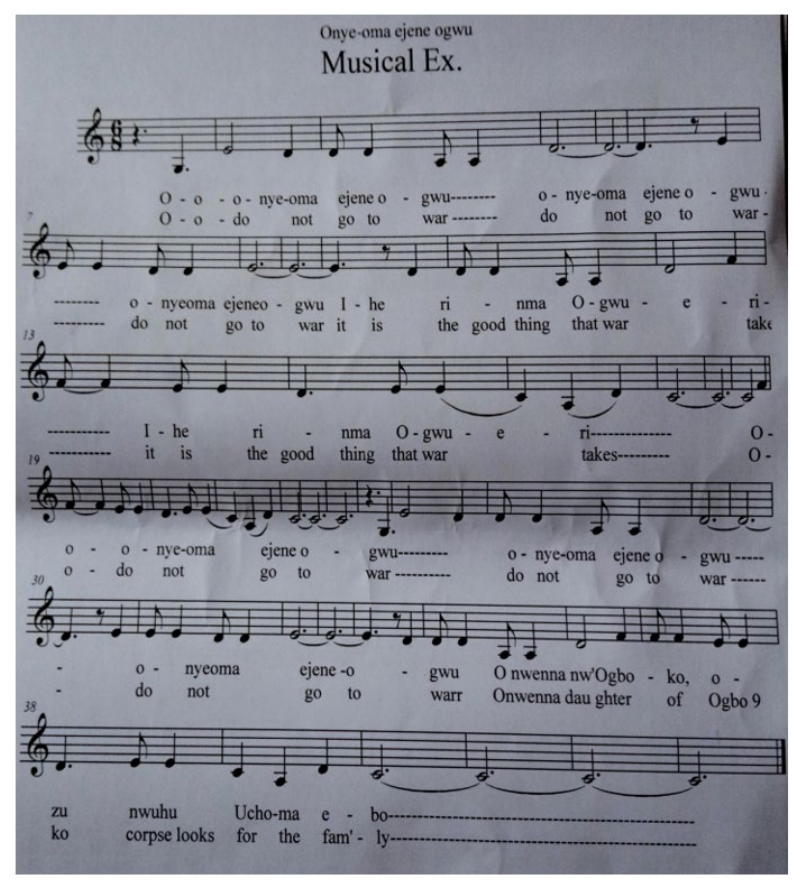




\section{APPENDIX II}

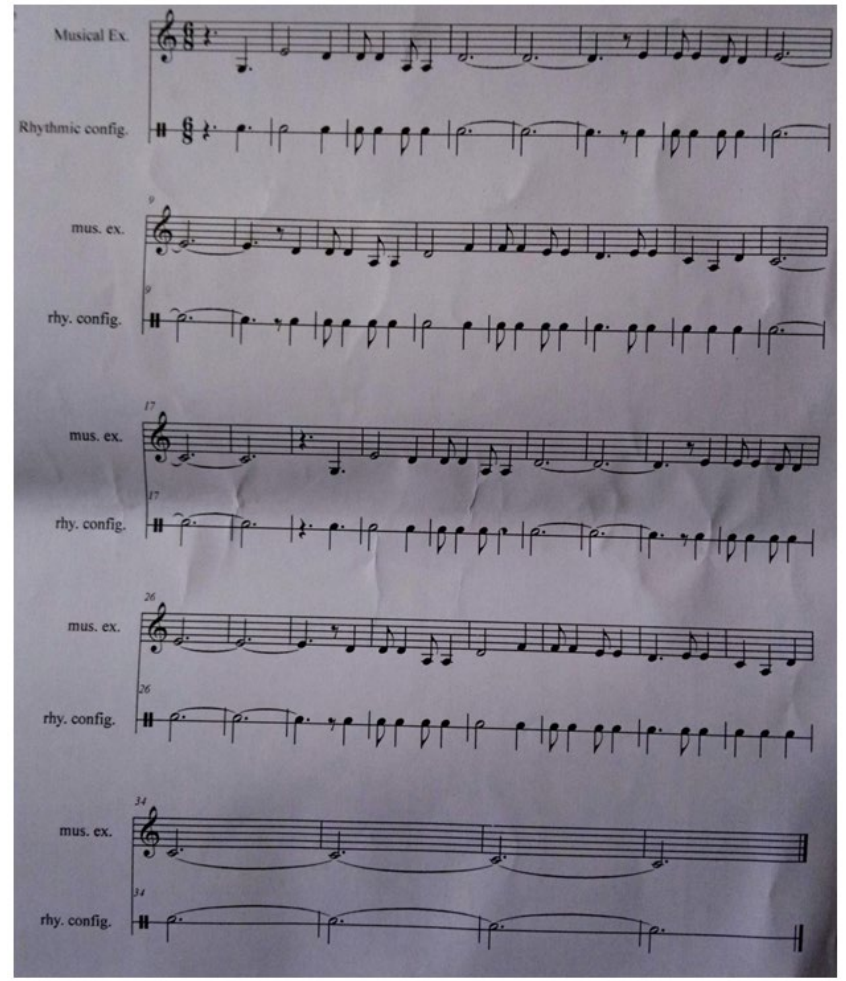

\section{APPENDIX III}

\section{NOTE}

- Eke, Nkwo, Afo, and Orie is designated market days among the Delta Ibos of Delta State, Nigeria. These market days are also similar to that of SouthEastern people of Nigeria.

- Ori is a type of food prepared from corn

- Nwabuzo Ukpali is the name of a man who hailed from Obio a neighbouring community to Owerre-Olubor community

- (akasi) a type of leaf that germinates \on the ground

- Ejo-Ofia Ikpekpe means cemetery 